Winter 2014

\title{
Pashtunistan's Future: The Global Executive or a Regional Solution
}

Joshua A. Kurtzman

Indiana University Maurer School of Law, jkurtzma@indiana.edu

Follow this and additional works at: https://www.repository.law.indiana.edu/ijgls

Part of the Comparative and Foreign Law Commons, and the International Law Commons

\section{Recommended Citation}

Kurtzman, Joshua A. (2014) "Pashtunistan's Future: The Global Executive or a Regional Solution," Indiana Journal of Global Legal Studies: Vol. 21 : Iss. 1 , Article 12.

Available at: https://www.repository.law.indiana.edu/ijgls/vol21/iss1/12

This Note is brought to you for free and open access by the Law School Journals at Digital Repository @ Maurer Law. It has been accepted for inclusion in Indiana Journal of Global Legal Studies by an authorized editor of Digital Repository @ Maurer Law. For more information, please contactrvaughan@indiana.edu.

\section{$\Psi$}

JEROME HALL LAW LIBRARY

INDIANA UNIVERSITY

Maurer School of Law
Bloomineton 


\title{
Pashtunistan's Future: The Global Executive or a Regional Solution
}

\author{
JOSHUA A. KURTZMAN*
}

\begin{abstract}
This note explores the transnational security issues associated with the Pashtunistan region following the withdrawal of NATO from Afghanistan in 2014. More specifically, at a time when this region is at a religious, governance, and globalization crossroads, this note posits that only two alternatives exist for addressing the security situation in this region. First, a global executive, or executives, could use their power to exert transnational security pressure through drone strikes or other pseudo-military alternatives. A second alternative, and one which this note considers much more promising, is the development of a "NATO. like" organization of Muslim nations to assist one another in addressing internal security issues. The note emphasizes that current global trends, particularly in the Muslim world, may create the impetus for such an organization and that the alternative would give rise to a continued unwanted expansion of executive power.
\end{abstract}

\section{INTRODUCTION}

Pashtunistan encompasses the western portion of Pakistan, which includes the Federally Administered Tribal Areas (FATA) and the southern and eastern portions of Afghanistan, most notably the Kandahar province that was the birthplace of the Taliban movement. ${ }^{1}$ Since the drawing of the Durand Line, the border between Pakistan and Afghanistan, in 1897, tribal Pashtuns in the region have always hoped

* Executive Notes Editor, Indiana Journal of Global Legal Studies, Volume 21; J.D. 2014, Indiana University Maurer School of Law; B.S. 2001, The United States Military Academy at West Point. I would like to thank Corinne Lewis, a partner at the international law firm of Lex Justi who focuses on international human rights law, whose mentorship and guidance greatly assisted in the editing and revising of earlier drafts.

1. CARL Forsberg, Inst. FOR the StUd. OF WAR, AFGHANISTAN RePORT 3: THE TALIBAN'S CAMPAIGN FOR KANDAHAR 9 (2009), available at http://www.understandingwar .org/sites/default/files/The_Talibans_Campaign_For_Kandahar.pdf.

Indiana Journal of Global Legal Studies Vol. 21 \#1 (Winter 2014)

(C) Indiana University Maurer School of Law 
and worked toward uniting the region again under the banner of Pashtunistan. ${ }^{2}$ It has often been thought that Pashtunistan was split in this manner as a "divide-and-rule British imperial decision" 3 that was made to disenfranchise and divide the power of the tribal Pashtuns. ${ }^{4}$ While the Durand Line has, in theory, split the Pashtuns, it has not eliminated their common language-Pashto-or their tribal code of conduct-Pashtunwali. ${ }^{5}$

Following the establishment of the Durand Line, Sir Percival Sykes stated, ${ }^{6}$ "Durand served his country right well, and generations yet unborn will benefit from the Durand Line that he negotiated."7 This statement, which was published in Sykes' 1926 book, in hindsight, now seems preposterous. ${ }^{8}$ This 1600 -mile dividing line between Pakistan and Afghanistan serves as an artificial boundary that ostensibly divides what is arguably the most dangerous ethnocentric region in the world between two nations. ${ }^{9}$ While this line has largely been ignored by the Pashtun tribesmen who live near it and who continue to live under the self-governance code of Pashtunwali, it has been impossible to avoid this region when examining the scourge of transnational terrorism. ${ }^{10}$ Security issues have plagued this region since the Soviet invasion of Afghanistan. This instability has led to a prevalence of transnational terrorism organizations taking root in the region with no single government who can address the region effectively or comprehensively.

Pashtunistan was chosen as the case study because it appears ungovernable. An ungoverned space is defined by four characteristics: (i) the lack of state penetration of society; (ii) the inability of the state to

2. Pepe Escobar, Welcome to Pashtunistan, ASIA TIMEs ONLINE (Nov. 6, 2009), http://www.atimes.com/atimes/South_Asia/KK06Df01.html.

3. Id.

4. See Scott Shane, The War In Pashtunistan, N.Y. TIMES (Dec. 5, 2009), http:/www.nytimes.com/ 2009/12/06/weekinreview /06shane.html?pagewanted=all\&_r=0 (explaining how the Durand Line has split the Pashtun people by placing 12 million Pashtuns within the borders of Afghanistan and 27 million on the Pakistani side of the border).

5. Id.

6. A British soldier, diplomat, traveler, and writer who wrote extensively on Iran and who was a senior British military and governmental representative in Pakistan, India, and Persia in the late 19th century. See ANTONY WYNN, OUR MAN IN PERSIA: THE LIFE OF SIR PERCIVAL SYKES-EXPLORER, CONSUL, SOLDIER, SPY 1-3 (2001).

7. David Rose, The Man Who Drew the Fatal Durand Line, STANDPOINT (Mar. 2011), http://standpointmag.co.uk/node/3728/full.

8. Id.

9. Anne Marie Payne, The Durand Line: History and Implications of British Imperial Policy in Afghanistan, at 3 (May 2012) (unpublished honors research thesis, The Ohio State University) (available at http://kb.osu.edu/dspace/bitstream/handle/1811/52071/Ann e_Payne_Honors_Thesis.pdf?sequence $=1$ ).

10. Id. at $3-4$. 
a monopolize the use of force; (iii) the inability of the state to control its borders; and (iv) whether the state is subject to external intervention by other states. ${ }^{11}$

First, state penetration can be evaluated by the "presence or absence of state institutions, the state of physical infrastructure, the prevalence of an informal or shadow economy, and social and cultural resistance to state penetration." 12 Section I of this note addresses Pakistan's nominal sovereignty over a large swath of Pashtunistan and Pakistan's lack of official government presence within this region. Instead of exerting its authority, the Pakistani government governs from an adjacent province, and any attempt to increase its influence is looked at as impermissible encroachment by the Pashtuns.

Second, the presence of a number of extremist organizations and their actions targeting both the Afghan and Pakistani governments demonstrates that the sovereign powers do not enjoy a monopoly on the use of force. These extremist organizations are able to advance their interests through the use of force, albeit it in a less conventional manner, at a level almost equivalent to the governments of Afghanistan and Pakistan. Third, Pashtuns living along the Durand Line ignore the border and do not view it as legitimate, thus satisfying the element describing control of the borders. ${ }^{13}$ Finally, the North Atlantic Treaty Organization's (NATO) presence in Afghanistan and the drone program of the United States in Pashtunistan adeptly exhibit the external intervention already ongoing in the region.

In light of these conditions, NATO withdrawal from Afghanistan in 2014 will likely produce an internationally significant security void in Pashtunistan. This note argues that there are two potential ways this situation could be addressed: one solution is through the actions of a global or transnational executive(s); another solution is through cooperation among Muslim nations to assist in policing their own region. It then argues that the second approach is superior to the first and should be pursued. This note begins with an analysis of Pashtunistan's impact on the global environment in the context of existing security threats in the region, the 2014 NATO withdrawal plan, and forecasted governance structures in the region post-2014. Next, this

11. ANGEL RABASA ET AL., UNGOVERNED TERRITORIES: UNDERSTANDING AND REDUCING TERRORISM RISKS 3 (2007).

12. Id.

13. See David Isby, AFghanistan: GRAVEYARD of EMPIRES: A NEW History of THE BORDERLAND 32, 461 (2010) ("There are 350 known unofficial crossing places to the current Afghanistan-Pakistan border, many more in practice. . . . [T] he Afghan Pashtun [during the war with the Soviets] did not view the border as legitimate and that practice has carried forward to the modern-day Taliban."). 
note defines the characteristics of a global executive, discusses the emergence of a global executive, and analyzes transnational security law impacts of the global executive. The note concludes by addressing the benefits and potential challenges of encouraging and fostering a regional solution.

\section{PAShtunistan's ImPACT ON THE Global StAGE}

The nineteenth and early twentieth century history of Afghanistan was a mere preamble to its current place on the world's stage. The story of the Durand Line is simply a "century-long saga of predatory colonialism, postcolonial insecurities, and incessant conflict ... [and] a tale of colonial cartography bequeathed to a postcolonial formation, bringing in its wake bitter fruits of oppression, violence, and war."14 Since the Russian departure from Afghanistan at the close of the Cold War, and the corresponding rise of the Taliban, Afghanistan's neighbors have been concerned with the upswing of Islamic fundamentalism. In the 1990s, Russia and Iran provided weaponry, training, fuel, and logistical resources to the Northern Alliance. ${ }^{15}$ This assistance was provided to prevent the spillover of "Islamic fundamentalism and antiShi'aism" into their countries. ${ }^{16}$ This region rose to the forefront of the global stage in a new and dynamic manner after serving as the genesis and operational headquarters for the terrorist attacks of September 11, 2001.

\section{A. Regional Conditions and the Rise of Extremism}

Pakistan is now well-known for its "suicide bombers, U.S. drone strikes, car bombs, the Taliban, a power crisis, displaced people, water shortages, and hostile relations with its neighbor, India." 17 These issues overwhelmingly rise out of the tribal areas dominated by the Pashtun people but have an impact on the world at large. While nuclear powers India and Pakistan exist together in a near-constant state of conflict

14. Tayyab Mahmud, Colonial Cartographies, Postcolonial Borders, and Enduring Failures of International Law: The Unending Wars Along the Afghanistan-Pakistan Frontier, 36 BROOKLYN J. INT'L L. 1, 48 (2010).

15. See Fiona Simon, Afghanistan's Northern Alliance, BBC NEwS (Sept. 19, 2001), http://news.bbc.co.uk/2/hi/south_asia/ 1552994.stm (explaining that the Northern Alliance is made up of non-Pashtun ethnic groups who were "united only in their desire to topple the ruling Taliban").

16. Hafeez Malik, The Taliban's Islamic Emirate of Afghanistan: Its Impact on Eurasia, 6 BRowN J. WORLD AFF. 135, 143 (1999).

17. Orla Orla MacRae \& Osman Haneef, Fathoming FATA. The Taliban Insurgency in Pakistan's Tribal Area, 6 YALE J. INT'L AFF. 115, 115 (2011). 
and tension that is felt globally, Pashtunistan is not responsible for this inter-state tension. However, the security threat arising from Pashtunistan is just as troublesome as this inter-state conflict and has arguably garnered more attention from global powers. This section examines the economic conditions leading to extremism in Pashtunistan and the security situation in the Pashtunistan areas in Afghanistan and Pakistan.

A vast majority of Muslim countries in the Middle East and Central Asia are in dire need of economic modernization, technical advice, and policy guidance to encourage economic growth. ${ }^{18}$ Nowhere is this need more prominent than in Pashtunistan. On the Pakistan side, the economy is structured to benefit traditional Maliks and radical Mullahs to the detriment of the local population, as evidenced by significant aid money being diverted from its intended recipient. 19 This lack of economic development contributes more to the growth of the insurgency than to a fervent belief in Islamic fundamentalism, as individuals see that joining the Pakistani Taliban, or a similar extremist group, provides an economic pathway to personal stability that is otherwise unavailable. ${ }^{20}$ An example of this troubling economic model is exhibited by the pay-scale difference between a low-level Pakistani Taliban fighter and a government policeman in the region. A "rank and file" Taliban fighter receives approximately $\$ 190$ a month, while the government provides its "tribal levies," which are hired based on merit, a paltry $\$ 43$ a month. ${ }^{21}$

The situation in Afghanistan is no better and only appears to be worsening. After the Russian withdrawal from Afghanistan, the Afghan people felt they would return to a state of peace and economic growth

18. See generally Regional Economic Outlook Update: Middle East and Central Asia Department, INT'L MONETARY FUND 1 (Apr. 20, 2012, 10:00 AM), http://www.imf.org/extemal $/ \mathrm{pubs} / \mathrm{ft} / \mathrm{reo} / 2012 / \mathrm{mcd} / \mathrm{eng} / \mathrm{pdf} / \mathrm{mena}$-update0412.pdf (discussing the issues faced by economies in the Middle East and Central Asia and how the Arab Spring and conflict has only exacerbated already weak economies while dealing with a global recession).

19. McRae \& Haneef, supra note 17, at 120 (discussing Nasreen Ghufran, Pushtun Ethnonationalism and the Taliban Insurgency in the NWFP of Pakistan, 49 ASIAN SURV. 1106 (2009) ("The Pakistani government's failure to provide the people of FATA desperately needed socioeconomic resources-including basic facilities in health, education, and communications-made it easier for Taliban militants to gain a foothold in the area. Furthermore, the government's inability to initiate both political and administrative reforms contributed to a vacuum in vital services that has been filled by Taliban and their supporters.")).

20. Id.

21. See Int'l Crisis Group, Pakistan: Countering Milltancy in FatA, Crisis GROUP ASIA REPORT 10 (2009); see also Khalid Khan, Pakistan's Tribal Police: Underpaid and Undervalued, THE AFPAK CHANNEL (Sep. 9, 2009, 4:55 PM), http://afpak.foreignpolicy .com/posts/2009/09/09/pakistans_tribal_police_underpaid_and_undervalued. 
but, instead, have faced two more decades of conflict.22 According to the World Bank, "97 percent of Afghanistan's roughly $\$ 15.7$ billion gross domestic product comes from international military and development aid and spending in the country by foreign troops. The economy is already contracting as troops prepare to leave, and future growth will be slower, especially in urban areas and areas of conflict." 23 Unfortunately, no area in Afghanistan is in a greater state of conflict than the Pashtunistan region. This conflict ensures that the economic conditions driving male economic providers to extremist organizations will exist and potentially worsen going forward.

The security situation in Pashtun regions of Afghanistan has been worsening since the Taliban resurgence in the mid-2000s. Much of northern and western Afghanistan has witnessed drastically improving security conditions and reconstruction. ${ }^{24}$ The opposite is true in the Pashtun regions. Since President Obama announced the "troop surge," attack levels have generally remained consistent or increased.25 This ultra-violent environment, experiencing almost three thousand violent acts a month, ${ }^{26}$ is made even more troubling by the fact that "[n]o Afghan army battalion is capable of operating without U.S. advisers, ... policemen spend more time shaking down people for bribes than patrolling, [and] front-line [Afghan] units often do not receive the fuel, food and spare parts they need to function."27 This confluence of factors foreshadows the fact that the Pashtun regions of Afghanistan will be largely ungoverned once NATO withdraws in 2014, like they were prior to September 11, 2001.

The security situation in Pakistan-controlled portions of Pashtunistan is worse than it is in Afghanistan. The mountainous region of Pashtunistan around the Durand Line has been referred to as the "grand central station of global Islamic militancy." 28 This region is

22. Victoria Schofield, Afghan Frontier: Feuding AND Fighting in CENTRAL ASiA 322 (2003).

23. Editorial, Afghanistan's Economic Challenges, N.Y. Times, July 20, 2012, http:// www.nytimes.com/2012/07/21/opinion/afghanistans-economic-challenges.html.

24. Michael Mihalka, Pashtunistan, NATO and the Global War on Terror: "If you don't fight, you cannot have peace in Afghanistan", 6 CHINA \& EURASIA F. Q. 1, 51 (2008).

25. Spencer Ackerman, Military's Own Report Card Gives Afghan Surge an F, WIRED (Sep. 27, 2012, 11:30 AM), http://www.wired.com/dangerroom/2012/09/surge-report-card/.

26. Id.

27. Rajiv Chandrasekaran, Afghan Security Force's Rapid Expansion Comes at a Cost as Readiness Lags, WASH. POST (Oct. 20, 2012), http://www.washingtonpost.com/world/na tional-security/afghan-security-forces-rapid-expansion-comes-at-a-cost-as-readiness-lags/2 012/10/20/38af200a-16cb-11e2-a55c-39408fbe6a4b_story.html.

28. Jason Burke et. al., Pashtunistan Holds Key to Obama Mission, The Guardian (Feb.14, 2009), http://www.guardian.co.uk/world/2009/feb/15/afghanistan-pakistan-obama? INTCMP=SRCH. 
where young men, bent on participating in transnational terror, journey to learn the skills necessary to deliver death and destruction against their perceived enemies. ${ }^{29}$ The Pakistani Taliban, or Tehrik-i-Taliban, and the insurgency, which is targeting the Pakistani government from within, further complicates this global issue. Proponents describe this conflict as "a rural, ultra-religious, nationalist movement fighting toothand-nail a corrupt, urban-based government as if they were a postcolonial fantasy of the noble tribal savage-a la Rousseau-fighting the colonialist West." 30 This insurgency has already successfully assassinated Pakistan Prime Minister Benazir Bhutto, conducted regular suicide bombings in major cities, and attacked the Pakistani Army Headquarters in Rawalpindi. ${ }^{31}$ Like Afghanistan, these conditions exhibit that this region will remain a global and transnational security threat following the NATO withdrawal from Afghanistan in 2014.

\section{B. The Plan for NATO's Withdrawal}

The 2014 NATO withdrawal plan, and the residual presence of NATO in Pashtunistan post-2014, is the subject of numerous national and international debates and significant anxiety throughout both the region and Western governments. While Mikhail Gorbachev, in his memoirs, described Russia's travails in Afghanistan as a "hopeless military adventure," the same cannot be said for NATO's efforts. ${ }^{32}$ NATO's guiding principle while in Afghanistan was to make every effort to "enable the Afghan authorities to provide effective security across the country and ensure that the country can never again be a safe haven for terrorists." ${ }^{3}$ Any counterinsurgency effort has a small likelihood of long-term success when the insurgent has a reliable and largely unchallenged cross-border sanctuary. ${ }^{34}$ Pakistani portions of Pashtunistan have served as this sanctuary. This condition will continue to hamper NATO's efforts as the conflict comes to a close.

A large degree of the long-term stability of Afghanistan, and $a$ fortiori Pashtunistan, is dependent upon the future performance of the Afghan National Security Forces (ANSF). NATO is optimistic that the

29. Id.

30. Escobar, supra note 2.

31. Scott Shane, The War In Pashtunistan, N.Y. Times (Dec. 5, 2009), http://www. nytimes.com/2009/12/06/weekinreview/06shane.html?pagewanted=all\&_r=0.

32. SCHOFIELD, supra note 22 , at 325.

33. NATO and Afghanistan, NATO (last updated June 18, 2013, 3:06 PM), http://www. nato.int/cps/en/natolive/topics_8189.htm?.

34. See, e.g., Rabasa, supra note 11. In this case, Pashtunistan serves as the ungoverned cross-border sanctuary that has given NATO forces in eastern and southern Afghanistan so much difficulty. 
handover to ANSF will be successful and contends that "Afghan soldiers are increasingly taking the lead in operations on Afghan soil ... [the] army and police, have proven able to maintain security in those areas which have already entered into transition." 35 This optimism surrounding the proficiency of the Afghan security apparatus has been dampened by a troubling spate of "insider attacks," which have reduced the credibility of the ANSF as a reliable force following NATO's withdrawal. ${ }^{36}$ While it is difficult to predict the success of the ANSF securing their country effectively, it is apparent that Afghan National Security Forces, while reportedly improving, are not yet an unwavering and incorruptible organization that can be relied on by the Western world to independently solve the Pashtunistan problem.

In May 2012, the leaders of NATO agreed upon an exit strategy that would allow NATO countries to withdraw over the course of two years. First, in mid-2013, NATO forces turned over security responsibility to Afghan security forces and assumed an advisory and support role. ${ }^{37}$ This turnover of security responsibility specified that Afghan forces will take control of all combat missions while receiving only logistical and enabler (helicopter, drone, and supply) support from NATO forces.38 The withdrawal plan demands that, by the end of 2014, an overwhelming number of NATO forces will be completely removed from Afghanistan after thirteen years of conflict. ${ }^{39} \mathrm{~A}$ troubling part of this withdrawal plan is that Afghanistan cannot afford to maintain its security forces and is relying on the donations of NATO countries to maintain their entire $\$ 4.1$ billion annual defense and security budget. ${ }^{40}$ This does not portend a bright future for the security environment in Pashtunistan if the international community fails to satisfy the budgetary needs of the Afghan security apparatus.

35. Chicago Summit Declaration on Afghanistan Issued by the Heads of State and Government of Afghanistan and Nations contributing to the NATO-led International Security Assistance Force (ISAF), May 21, 2012.

36. David S. Cloud, As 'Insider Attacks' Grow, So Does U.S.-Afghanistan Divide, L.A. TIMES (Nov. 7, 2012), http://articles.latimes.com/2012/nov/07/world/la-fg-afghan-insiderattacks-20121107 ("There have been 41 insider attacks by Afghan soldiers and police this year, killing 35 Americans and 22 people from other countries with forces in Afghanistan. Cmdr. William Speaks, a Pentagon spokesman, said 'significantly more' Afghans than foreigners have died in the attacks.").

37. Dave Boyer, NATO Finalizes Afghan Withdrawal Plans, WASH. TIMEs (May 21, 2012), http://www.washingtontimes.com/news/2012/may/21/nato-leaders-approve-afghan-h andover-plan/?page=all.

38. Id.

39. Id.

40. Id. 


\section{Forecasted Governance Structures Remaining in 2014}

The governments of Afghanistan and Pakistan have not inspired confidence in Western countries, and this condition has, unfortunately, not improved over time. NATO and Western nations now worry about the fragility of the Afghan government post-withdrawal, upcoming Afghan elections, President Karzai's unwillingness to sign a long-term security agreement, and the lack of control the Pakistani government can exert over its portion of Pashtunistan.

\section{Concerns with the Afghan Government}

The history of government in Afghanistan is a tumultuous one, and the current incarnation is no less so. ${ }^{41}$ In 2001, NATO, and the United States, ${ }^{42}$ felt a strong centralized government in Kabul was indispensable for keeping the ethnically disparate nation together. ${ }^{43}$ This view is now tragically considered foolish by many who believe such a plan was not worth the time or cost because it might never have been possible to unite Afghanistan under a strong central government in the first place. ${ }^{44}$ The history of Afghanistan disappointingly concurs with this updated assessment. The recent history of Afghan governance also complicates withdrawal efforts as counterinsurgency experts attest; success in a conflict like this is largely predicated on the quality of the government you are supporting. ${ }^{45}$ In the case of Afghanistan, the government is among the most corrupt in the world; "[o]ut of 180 countries, Transparency International ranks [Afghanistan], in terms of corruption, 179th, better only than Somalia." 46 This corruption, even when NATO forces are present in large numbers and still have an impact in the country, does not bode well for the future stability of this

41. Adam Ritscher, A Brief History of Afghanistan, Speech at a Students Against War Teach-In (2002) (available at http://www.afghangovernment.com/) (discussing the series of coups, assassinations, and autocratic rule that has been prevalent in Afghanistan ruling bodies over the course of the last 200 years).

42. At this point the terms are almost interchangeable due to the United States' influence over NATO.

43. Thomas Barfield, Afghanistan's Ethnic Puzzle: Decentralizing Power Before the U.S. Withdrawal, 90 FoREIGN AFF. 54, 54-55 (2011).

44. Stephen Biddle, Fotini Christia \& J. Alexander Their, Defining Success in Afghanistan: What Can the United States Accept?, ForEIGN AFF. 2010, available at http://www.foreignaffairs.com/articles/66450/stephen-biddle-fotini-christia-and-j-alexander -thier/defining-success-in-afghanistan.

45. Robert D. Blackwill, Plan B in Afghanistan: Why a De Facto Partition Is the Least Bad Option, 90 Foreign AFF. 42, 43 (2011).

46. Id. 
government. Afghanistan's corruption also negatively affects its ability to provide credible governance to its people, or its ability to secure Pashtunistan.

Three significant occurrences have led to the Afghan government losing almost all credibility in the eyes of its people. First, after the invasion of 2001, many Afghians thought they would have much more local self-rule and autonomy than they currently enjoy. ${ }^{47}$ Next, the Afghan federal government also lost a tremendous amount of credibility based upon the 2009 presidential election, which many believe was rife with corruption..$^{48}$ Finally, the government has been browbeaten by the insurgency's efforts to target Afghan civilians. A political science professor in Kabul said these efforts "show the world the Afghan government is too weak to prevent [these sorts of attacks]." 49 All of these factors, coupled with the inherent corruption of the Afghan government, make it very likely that the eastern and southern regions of Afghanistan-Pashtunistan-will be ungoverned or ineffectively governed by weak local governance institutions following the withdrawal of NATO in 2014.

Further complicating the Afghan government situation, and causing regional uncertainty, is the Afghan presidential election scheduled for April 5, 2014. The Afghan Constitution prohibits President Karzai from pursuing another term as president, but no Afghan chief executive has ever left office of his own volition. ${ }^{50}$ Assuming this election occurs as scheduled, there are two good reasons for the international community to be concerned. First, the timing of this election is troublesome as a new, and therefore relatively inexperienced, national leader will assume control of Afghanistan as NATO security forces are exiting the country. Transitions of power, particularly in nascent democracies, are fragile. To add the withdrawal of the NATO "security blanket" to the turbulence of this transition allows one to infer that the Pashtunistan security situation may not be well addressed. Second, the Afghan elections in 2009 , when over 150,000 NATO soldiers were in the country, were incredibly violent, which kept many voters away from the polls, particularly in the Pashtun areas of the country. ${ }^{51}$ If Pashtun voters are disenfranchised again, further instability could result. The situation on

47. Barfield, supra note 43 , at 54 .

48. See Sabrina Tavernise \& Abdul Waheed Wafa, U.N. Official Acknowledges 'Widespread Fraud' in Afghan Election, N.Y. TIMES (Oct. 12, 2009), http://www.nytimes .com/2009/10/12/world /asia/12afghan.html?_r=0.

49. Mihalka, supra note 24 , at 55 .

50. Id. at 64-65.

51. Matthew Rosenberg, Afghans Say Presidential Election Date Is. Set for April 2014, N.Y. TIMES (Oct. 30, 2012), http:// www.nytimes.com/2012/10/31/world/asia/afghan-electio n-date-is-set-for-2014.html. 
the Afghan side of Pashtunistan does not encourage anyone familiar with the region to believe that the transnational security threat emanating from there can be addressed independently by the Afghan government.

\section{Concerns with the Pakistani Government}

For the areas of Pashtunistan that fall within Pakistan, the governmental concerns are not as complex as those in Afghanistan. This is because there is ostensibly no Pakistani government control of the Pashtuns, and the Pakistani government is largely consumed with preventing its own demise from its Hindu neighbor, nuclear-power India.

The portions of Pashtunistan that fall within the borders of Pakistan make up a region known as the FATA, which is bordered to the east by the Northwest Frontier Province (NWFP), which is closer to Islamabad. While the governor and bureaucracy of the NWFP are responsible for the administration of the FATA, there is no indication that they actually exert any control over the administration of the FATA. ${ }^{52}$ Instead, control of the FATA has been ceded to prominent Islamic Pashtun leaders who do not recognize the old practice of local tribal councils participating with an agent of the Pakistani government. ${ }^{33}$ This control has led to increased "radicalization of its population [that] seems to be an unstoppable process." ${ }_{44}$ This lack of control and increased radicalization has led to efforts to control the area by the Pakistani government. These efforts have been largely unsuccessful and have further distanced the Pashtuns from the government of Pakistan, thus sending the Pashtuns messages about the goals of their federal government. 55 This radicalization, in combination with the central government's inability to exert any control over the Pashtun areas of the country, creates a situation with an increasing likelihood that Pashtunistan will remain an ungoverned space that is

52. See Ijaz Khan \& Pervaiz Iqbal Cheema, NBR Analysis: Challenges Facing Pakistan's Federally Administered Tribal Areas (FATA), 19 NAT'L BUREAU ASIAN RES. 1, 19 (2008), available at www.nbr.org /publications/analysis/pdf/vol19no3.pdf.

53. Tribal Analysis Center, Pashtunistan, Pakistan's Shifting Strategy? (May 2012), available at http://www.tribalanalysiscenter.com/PDF-TAC/Pashtunistan\%20Shifti ng\%20Strategy.pdf.

54. Id.

55. See generally Husain HaQqANI, PAKISTAN: BeTWEen Mosque AND MILITARY 169 (2005) (discussing how Baluch \& Pashtun nationalists interpreted Pakistani military action in Pashtunistan as a provocation motivated by the desire of the government and the Pakistani army to centralize authority over the region). 
the "grand central station" of Islamic fundamentalism and transnational terror. ${ }^{56}$

Compounding the already troubling governance conditions in Pashtun regions of Pakistan is the government's preoccupation with India. While Pashtunistan, and the Pashtun population generally, becomes more radicalized and ungovernable, the Pakistani government and elites continue to focus on the threat from India. Addressing the threat from India has become such a preoccupation that "[p]rojection of [the] threat from India is fundamental to the survival of the Pakistani establishment." 57 The conflict with India, the government's lack of control over the Pashtuns, the restructuring of the country, and the struggle for democracy are all links in the same chain of instability that weighs down the government of Pakistan. ${ }^{58}$ This chain prevents Pakistan from adequately addressing its Pashtunistan problem, requiring this transnational space to be addressed by the world at large.

\section{THE RISE OF THE GLOBAL EXECUTIVE}

The concept of a global or transnational chief executive has developed over the latter parts of the twentieth century and early part of this century as an unintended consequence of increased global interconnectedness. A confluence of security and economic events served to usher in an age in the United States and, perhaps a handful of other countries, where chief executives' power and global reach is unrivaled by their predecessors or contemporaries in the legislature. This section will attempt to define the amorphous concept of a global executive, explain the emergence of the global executive, and examine how the global executive's exercise of power affects Pashtunistan and the global security environment generally.

Before the examination of what defines a global executive, it is necessary to understand a fundamental principle: to act, a global executive must be advancing or enforcing an international norm of some nature. For our purposes here, it is the President of the United States who has been addressing Pashtunistan and advancing the norms outlined below. There are "three layers to the international cultural

56. Jason Burke et. al., Pashtunistan Holds Key to Obama Mission, THE GUARDIAN (Feb, 14, 2009), http:/www.theguardian.com/world/2009/feb/15/afghanistan-pakistan-oba ma.

57. Ayesha Siddiqa-Agha, Pakistan's arms Procurement and Military Buildup, 1979-1999: IN SEARCH OF A POLICY 56 (2003).

58. Ijaz Khan, Contending Identities of Pakistan and the Issue of Democratic Governance, 2 PEACE \& DEMOCRACY S. ASIA 50, 53, 55 (2006). 
environments in which national security policies are made."59 One layer includes security alliances (e.g., NATO, the Organization of American States, and the Association of Southeast Asian Nations) and security agreements (the Strategic Arms Limitation Talks Treaty, the Nuclear Non-Proliferation Treaty). ${ }^{60}$ The next layer is the world political culture that recognizes the "rules of sovereignty and international law" and the "transnational political discourse" carried out by various nongovernmental organizations. ${ }^{61}$ The final layer provides a norm that a global executive may enforce, which is the "international patterns of amity and enmity." 62 This norm shapes our perceptions of nations, people, or cultures based upon how they interact with each other. ${ }^{63} \mathrm{All}$ of these norms or layers are present in the U.S. President's approach to Pashtunistan.

\section{A. Global Executive Defined}

Attempting to define or describe something as amorphous as a "global executive" is exceedingly difficult, but it is less complicated in the United States post 9/11 because of the United States government's assumed role in furthering its own, and its allies', security interests. To that end, a global executive, in this case the President of the United States, can be defined as a chief executive from a hegemonic power, who serves at a time when great economic and security concerns exist, and who exercises transnational power with little or no legislative oversight or acquiescence.

It should be relatively apparent why a global executive must be the chief executive of a hegemonic power. While a chief executive from a nonhegemonic power may have a transnational impact through a smaller military intervention, it is exceedingly difficult for this impact to be global in scope or last for an indeterminate length of time. The checks that limit an executive's ability to have a transnational impact can come from a variety of sources. First, an executive can be limited by the source of his power of persuasion. For example, "an executive whose power is based on personal charisma . . . finds it necessary to spend

59. Ronald L. Jepperson, Alexander Wendt \& Peter J. Katzenstein, Norms, Identity, and Culture in National Security, in THE CULTURE OF NATIONAL SECURITY: NORMS AND IDENTITY IN WoRLD POLITICs 33, 34 (Peter J. Katzenstein ed., 1999).

60. Id.

61. Id.

62. Id.

63. Id. (discussing how Canada and Cuba are viewed and treated differently by the United States government based upon their position, whether real or imagined, regarding the United States and our interests). 
precious time and energy reinforcing the public's favorable perceptions." 64 Additionally, and more tangibly, the limiting effects on executive power can be produced by "constitutional limitations, strong liberal tradition, powerful legislature ... political parties, the press, and the electorate." 65

President Clinton's presidency is an example of how even the chief executive of a hegemonic power may not have a global impact unless the right conditions exist. During President Clinton's first term, the vast majority of his impact and accomplishments took place primarily on the domestic front and had nearly no global impact. ${ }^{66}$ It was not until the latter part of his first term and his second term that he agreed to the North American Free Trade Agreement (NAFTA) and influenced the NATO intervention in Kosovo. ${ }^{67}$ Very little is said about the impacts the chief executive of Mexico or Canada had on the ratification of NAFTA. 68 Instead, the focus of the agreement, and the debate over NAFTA since its signing, is on President Clinton's role and the effects the agreement has had on the world.69 Similarly, while many other nations were involved in the Kosovo operation, it was President Clinton who was seen as the leader and dominant influence on the intervention. ${ }^{70}$ It was President Clinton who, after the breakdown of NATO-backed peace talks, made the decision to launch a bombing campaign in what was ostensibly a civil war. ${ }^{71}$ These two actions, one economic and one defense-related, are perfect examples of a global executive carrying out actions illustrative of its hegemonic power.

64. Marcus E. ETHRidge \& Howard Handelman, Politics in a Changing World: A COMPARATIVE INTRODUCTION TO POLITICAL SCIENCE 197 (6th ed. 2010).

65. S.N. Ray, Modern Comparative Politics: Approaches, Methods and Issues 225 (3rd ed. 2004).

66. See generally American President: A Reference Resource - Bill Clinton, MILLER CENTER, http://millercenter.org /president/clinton/essays/biography/print (last visited Nov. 9, 2012) (explaining how President Clinton's first-term was largely consumed with addressing the national deficit and a failed attempt to institute a national health care system).

67. See generally Jim Garamone, Clinton Makes Case for Kosovo Intervention, U.S. DEPT. OF DEFENSE (Mar. 24, 1999), http://www.defense.gov/news/newsarticle.aspx?id=420 01 (discussing President Clinton's views on why force may be necessary in Kosovo).

68. See generally Andrea Ford, A Brief History of NAFTA, TIME (Dec. 30, 2008), http://www.time.com/time/nation/article/0,8599,1868997,00.html (discussing NAFTA's impact on trade generally and recommendations for Mexico's and Canada's focus).

69. See id.

70. See generally Sebastien Barthe \& Charles-Philippe David, Kosovo 1999: Clinton, Coercive Diplomacy, and the Use of Analogies in Decision Making, 8 Whitehead J. Dipl. \& Int'l Rel. 85 (2007).

71. See Benjamin Schwarz \& Christopher Layne, The Case Against Intervention in Kosovo, THE NATION 1-2 (Apr. 19, 1999), http://www.thenation.com/article/case-againstintervention-kosovo\#. 
A president will likely have the ability to exercise increased war powers during a time when global economic or security concerns make the executive's constituency demand action and allow for the use of expansive supra-constitutional powers. The idea of state survival, or the survival of the state's values and respect for sovereignty, is frequently invoked as a rationale for expanding executive power. This concept was summarized well by President Roosevelt's attorney general during World War II, Francis Biddle, when he said, "the Constitution has never greatly bothered any wartime president."72 Similarly, President Lincoln, when discussing governmental power during the Civil War stated, "[a]re all the laws, but one, to go unexecuted, and the government itself go to pieces, lest that one be violated?"73 While these two statements arose out of security concerns, they speak to a broader principle: when exigent circumstances exist, an executive may exercise a level of power above what is normally permitted or expected. There are fewer instances of global executives asserting themselves during an international economic crisis-President Roosevelt did so on a national level during the Great Depression-largely because the world economy has only recently become globalized and interconnected in a way that allows for a chief executive to have a global impact. ${ }^{74}$ Infra, this paper will examine how these occurrences, both defense and economic in nature, are more prevalent today than ever before, thus allowing a modern global executive to emerge and engage the world on a variety of substantive issues throughout their time in office.

Finally, to be a global executive, one must exercise power outside the confines of legislative approval and oversight or through creative legal interpretation that serves to expand an executive's authority or mandate. To return to an example used previously, the Kosovo intervention is a perfect example of the United States President operating as a global executive and exercising power outside of

72. Scott M. Matheson, JR., Presidential Constitutionalism in Perilous Times 75 (2009).

73. ABRAham LinCOLn, Message to CongRess (July 4, 1861), reprinted in The Official Records of the Union and Confederate Armies, Series IV, I, 311-321 (1900) (discussing the habeas corpus litigation on-going in multiple courts throughout the Union).

74. As evidence of this proposition: the World Trade Organization, whose purpose is to promote free trade and has become closely associated with globalization, was founded in 1995; and the Group of 8 (G8), which holds yearly meetings to establish consensus among industrialized nations on economic growth and other issues, was initially formed in 1975 and only fully formed in 1998. See, e.g., Profile: World Trade Organization, BBC NEwS (Feb. 15, 2012, 11:31 AM), http://news.bbc.co.uk/2/hi/europe/country_profiles/2429503.stm; Stephanie Lee, Alexandra Silver \& Zachary Laub, The Group of Eight (G8) Industrialized Nations, CoUnCIL ON FOREIGN RELATIONS (last updated June 14, 2013), http://www.cfr.org /global-governance/group-eight-g8-industrialized-nations/p10647. 
legislative oversight. In this case, the United States House of Representatives demanded the President seek congressional approval under the War Powers Resolution and was rebuffed.75 The Kosovo operation "was the first combat operation to continue beyond sixty days without express statutory authorization, in apparent contravention of the War Powers Resolution."76 This was a defining act that is illustrative of how a global executive takes action-irrespective of a desire of the legislature to impact the policy-that has transnational effects.

\section{B. The Emergence of the Global Executive}

The administration has gone to great lengths to avoid the legal restraints that normally would apply under our legal system. They have argued that the laws of war are not applicable because we are fighting a new type of enemy. They have argued the criminal laws are not applicable because we are fighting a war. ${ }^{77}$

I can understand why some administration lawyers might have wanted ambiguity so that every hypothetical option is theoretically open, even those the President has said he does not want to exercise. But war doesn't occur in theory and our troops are not served by ambiguity. They are crying out for clarity. ${ }^{78}$

What Senators Jeff Bingaman and Jon McCain are expressing is their frustration with the powers of the modern global executive. As Barry Friedman stated, "as globalization proceeds, executive power will be enhanced simply because of the nature of the decisions being made."79 This phenomenon has occurred in Western Europe as integration into the European Union occurs: "executive authority has

75. See generally Letter from Representative Tom Campbell and John Conyers to President Clinton (Dec. 1, 1999) (available at http:/www.house.gov/campbel/990219.htm) (asking President Clinton to delink the military sanctions against Iraq).

76. Geoffrey S, Corn, Clinton, Kosovo, and the Final Destruction of the War Powers Resolution, 42 WM. \& MARY L. REV. 1149, 1154 (2001).

77. Press Release, U.S. S. Comm. on Env't \& Pub. Works, National Defense Authorization Act for Fiscal Year 2006, available at http://www.epw.senate.gov/pressitem. cfm?party=rep\&id=252718.

78. 151 CONG. REC. S11062 (daily ed. Oct. 5, 2005) (statement of Sen. McCain).

79. Barry Friedman, Federalism's Future in the Global Village, 47 VAND. L. REV. 1441, 1477 (1994). 
increased vis-a-vis the legislative bodies." 80 These complaints and Friedman's assertion highlight three key elements that outline and explain the emergence of the global executive in the twenty-first century: an inability of constitutional limits to control the global executive, a crisis or multitude of crises that allows an executive to expand his powers by invoking the notion of state survival, and the global reach and interconnectedness of problems that allow an executive to have a transnational impact.

The global executive has emerged over the last thirty years in part because constitutional systems have significant difficulty in controlling the actions of a nation's chief executive. This is true both in economic and security crises. First, an apt example of supraconstitutional powers in a security context occurred in Great Britain in 1969 and continued until the early 2000s. In 1969, Operation Banner, an emergency deployment of British troops to Northern Ireland, was launched in response to rising tensions between Protestants and Catholics in Belfast. ${ }^{81}$ Significantly, the deployment of the British military was not based on United Kingdom law. ${ }^{82}$ Instead, the British Prime Minister ordered the deployment in response to a request from the Prime Minister of Northern Ireland. ${ }^{83}$ This state of affairs and action by global executives is now commonplace with the drone program of the United States, and its impacts in Yemen, Pakistan, and North Africa as the most apparent examples. ${ }^{84}$ The emergence of the global executive in the modern age of terrorism has been expedited by the fact that states now "take up the challenge of protecting civilians and place it center stage in the life of the State" and that constitutions are not able to curtail executives when they invoke the need to protect the citizenry. ${ }^{85}$

Furthermore, the global executive has emerged over the last several decades due to the nature of modern conflict and financial globalization, coupled with the fact that modern crises seemingly always have a global impact due to the increased interconnectedness of the world. The global executive, regardless of the geographical location of his country, must respond to crises like Greece's inability to get their fiscal house in

80. Id.

81. See Chris Thornton, Brits in Northern Ireland: Mission Over, TIME (Aug. 1, 2007), http://www.time.com/time/world/article/0,8599,1648606,00.html.

82. See David Turns, The 'War on Terror' Through British and International Humanitarian Law Eyes: Comparative Perspectives on Selected Legal Issues, 10 N.Y. CITY L. REV. 435, 446 (2007).

83. See id.

84. See generally Micah Zenko, Council on Foreign Rel., Policy InNovation Memorandum No. 31: Transferring CIA Drone Strikes to the Pentagon (2013), available at $\mathrm{http}: / / \mathrm{www} . c f$ r.org/drones/transferring-cia-drone-strikes-pentagon/p30434.

85. PHILIP BOBBITT, TERROR AND CONSENT 181 (2008). 
order ${ }^{86}$ or a group of fundamentalists in rural Yemen. ${ }^{87}$ In the former example, heads of state of various EU nations acted collectively as a sort of global executive, while in the latter example President Obama has instituted a campaign to target $\mathrm{Al}$ Qaeda elements in rural Yemen.88 These are just two recent and relevant examples of expanding executive power when a global executive is called on to address issues that a century ago would not have been of any particular concern. Current counterterrorism efforts and the examples from Northern Ireland and Kosovo aptly illustrate how modern security concerns have led to the emergence of the global executive.

On the economic front, the renowned author Saskia Sassen has identified four critical developments that have allowed economic issues to embolden the global executive. These developments include the building of the global corporate economy; "intergovernmental networks centered largely on the executive branch" like the Group of 8 (G8), the International Monetary Fund (IMF) and the World Trade Organization (WTO) interacting almost exclusively with the executive branch; and the privatization of public functions reducing the legislature's oversight. ${ }^{89}$ The combination of global economic and security concerns has created a situation where an empowered global executive can exercise transnational power on a daily basis due to the number of crises with a global scope.

86. See, e.g., John Cassidy, Greek Chaos Threatens World Economy-and Obama, THE NEw YORKER (May 9, 2012), http://www.newyorker.com/online/blogs/johncassidy/2012/05/ greek-chaos-threatens-world-economy--and-obama.html (discussing how "if we've learned (or relearned) one thing in the past few years, it is that modern economies are closely interconnected. What happens to Greece matters for the rest of Europe, and what happens to Europe matters for the rest of the world, us included. Contagion and the threat of contagion are facts of modern life.").

87. See Christopher Swift, The Drone Blowback Fallacy, FoREIGN AFFaIRS (July 1, 2012), http://www.foreignaffairs.com/articles/137760/christopher-swift/the-drone-blowback -fallacy (discussing the Central Intelligence Agency's efforts in rural Yemen to thwart the growth of Al Qaeda in the Arabian Peninsula (AQAP) and the use of the executive -driven drone-strike program).

88. Yara Bayoumy, Insight: In Yemen, Al Queda Gains Sympathy Amid U.S. Drone Strikes, REUTERS, Dec. 13, 2013, http://www.reuters.com/article/2013/12/13/us-yemen-usdrones-insight-idUSBRE9BC0A020131213.

89. Saskia Sassen, Shadow Elite: What's Behind Surging Executive Power? Globalization, HUFFINGTON POST (Apr. 15, 2010, 6:50 AM), http://www.huffingtonpost. com/saskia-sassen/emshadow-eliteem-whats-be_b_538513.html. 


\section{The Global Executive, Pashtunistan, and Transnational Security Law Impacts}

When viewing the role of the global executive through the context of Pashtunistan, it is impossible to avoid focusing on the actions of the President of the United States, who fits the definition of a global executive as posited earlier. Whether because the United States faces the greatest threat of all Western nations from transnational terror emanating from Pashtunistan or because of another reason, the United States President is undoubtedly the most engaged global player. Because of this, the remaining discussion in this section will focus on the repercussions of current policies and the potential for alternative policies.

The United States' primary approach to the insecurity in Pashtunistan, outside of the ground war in Afghanistan, has largely been characterized by the drone program. In 2010, the President ordered 118 attacks targeting militants in Pashtunistan, which lead to the deaths of 581 militants and cost approximately $\$ 118$ million. ${ }^{90}$ This tremendously kinetic approach to addressing the lack of security and governance provides numerous transnational legal issues. First, the secrecy inherent in the program and the inability of outsiders, such as media and civil society organizations, to gain access to Pashtunistan mean that the program is held to a very low level of public scrutiny or accountability. ${ }^{91}$ This criticism may be somewhat allayed by the fact that the executive branch may be subjecting these strikes to a high level of scrutiny and accountability. However, it is difficult to combat this criticism due to the concentration of the program within the executive branch.

The impacts of this lack of transparency on transnational security law are currently difficult to fully ascertain. Unfortunately, they could have damaging long-term impacts. For instance, Israel has instituted a similar drone program that it is using to target militants in Gaza, ${ }^{92}$ including the targeted killing of the leader of the Hamas military wing

90. See Selig S. Harrison, America Builds Pashtunistan, The NATIONAL INTEREST (Feb. 28, 2011), http://nationalinterest.org/commentary/america-builds-pashtunistan-4928.

91. See STANFORD INT'L HUMAN RIGHTS \& CONFLICT RESOLUTION CliNIC ET AL., LIVING Under DRones: DEATH, INJURY, AND TRAUMA to CIVILIANS From US DRONE PraCtices in PAKISTAN (2012), available at www.livingunderdrones.org/report/.

92. See Fares Akram \& Isabel Kershner, Israeli Drone Strike Kills Militants in Southern Gaza, N.Y. TIMES (Oct. 29, 2011), http://www.nytimes.com/2011/10/30/world/mid dleeast/israeli-drone-strike-kills-militants-in-gaza.html. 
and the subsequent flaring of tensions in November 2012,93 This program-and its accompanying secrecy-is only the first of what will likely be many copycat programs throughout the world. This proposition is made more troubling by the fact that international law does not speak to how these programs should be governed, audited, or deemed legal. ${ }^{94}$ With no international legal framework in place, nations with the capacity to produce drones can look to the United States drone program as a quasi-rationale and target internal dissidents-or external dissidents in a country without the capability or power to adequately respond. This absence of a legal framework threatens to create a raceto-the-skies mentality that could negatively and permanently impact modern warfare. A reliable international framework must be developed to forestall this potential, but the assumed immediacy of threats in Pashtunistan prevents the development of this framework.

Besides the transparency concerns addressed above, another concern is the effectiveness of the program and the impact it has on the local Pashtun population. A global executive, by necessity, takes action and makes decisions from afar. It is tough to know whether a program is effective, or even could be effective, without a deep and personal knowledge of the issue it is addressing. What is known is that the drone program inherently causes tremendous mental health issues for innocent tribespeople living in the targeted areas within Pashtunistan. ${ }^{95}$ Others contend that the attacks are radicalizing the Pashtun people, thereby empowering the local Islamic fundamentalists who preach resistance against the Pakistani government and the West. ${ }^{96}$ This could lead to the conclusion that the global executive's exercise of power is exacerbating, instead of abating, the security threat coming from Pashtunistan. The transnational security law impact of a global executive program that leads to the increased enlistment of Pashtuns in radical organizations cannot be understated. This

93. See Steve White, "Israel Has Opened the Doors of Hell": Hamas Warning After Air Strike Kills Commander, MIRROR (Nov. 14, 2012, 7:55 PM), http://www.mirror.co.uk/news/ world-news/hamas-leader-killed-by-israel-air-1436385.

94. See, e.g., Adam Entous, Siobhan Gorman \& Evan Perez, U.S. Unease Over Drone Strikes, WALL STREET J. (Sep. 26, 2012, 6:59 AM ET), http://online.wsj.com/article/SB1000 0872396390444100404577641520858011452.html (discussing how Obama administration officials are attempting to identify a legal framework that could serve to govern the drone program).

95. See generally STANFORD INT'L HUMAN RIGHTS \& CONFLiCT RESOlUTION Clinic, supra note 91, at 20 (describing how "A Pakistani psychiatrist, who has treated patients presenting symptoms he attributed to experience with or fear of drones, explained that pervasive worry about future trauma is emblematic of 'anticipatory anxiety,' common in conflict zones.").

96. See Harrison, supra note 90. 
radicalization could serve to further destabilize conditions throughout Pashtunistan, both in Pakistan and in Afghanistan, and lead to the perception amongst the Pashtuns that the anxiety they feel because of the presence of drones amounts to state-sponsored terrorism. If the result of the program is that Pashtuns feel terror must be met with terror and more young men enter the ranks of terrorist organizations, a resolution of security issues in Pashtunistan is not likely to occur.

Antonio Cassese argues that a global executive has another option when addressing transnational terror. This option is referred to as the "peaceful option," in which a global executive leads an enforcing of criminal law on the national and transnational levels, sequestrating assets, and securing international police and judicial cooperation in the investigation, extradition, and prosecution of terrorist networks and individual terrorist suspects. ${ }^{97}$ This option could have more positive impacts on transnational security law, but one wonders if a global executive could cede that much authority to a loose process of multistate cooperation. ${ }^{98}$ The effectiveness of this "peaceful approach" in an ungoverned space like Pashtunistan is also precarious at best. With no effective governance in Pashtunistan, who would the global executive cooperate with to arrest and extradite terror suspects? How would the prosecution of these individuals occur? What transnational security law would be enforced? These questions make the likelihood of this approach being implemented remote.

The view exists that the global executive has the autonomous ability to exercise "the employment of unilateral military force to enhance survival prospects, maximize power, and increase security relative to other states[, and this exercise of power] is neither ephemeral nor atavistic, but is rather the fundamental and immutable fact of international relations." 99 This is an impractical manner in which to employ transnational executive power. The following alternative, which foregoes the global executive for a multi-state regional solution, is practical and has the potential to offer a more realistic improvement to the security and economic conditions in Pashtunistan.

97. See generally Antonio Cassese, The International Community's "Legal" Response to Terrorism, 38 INT'L \& COMP. L.Q. 589, 590 (1989).

98. See DAVId MCClEAN, INTERNATIONAL CO-OPERATION IN CIVIL AND CRIMINAL MATTERS 6 (2002) (discussing how states historically have been unwilling to seek or establish international cooperation as a means of prosecuting and punishing terrorists, opting instead to use solutions within their own law enforcement and legal jurisdictions).

99. William C. Bradford, International Legal Regimes and the Incidence of Interstate War in the Twentieth Century: A Cursory Quantitative Assessment of the Associative Relationship, 16 AM. U. INT'L L. REV. 647, 654-55 (2001). 


\section{LOOKING INWARD TO CONFRONT CURRENT AND FUTURE PROBLEMS}

An alternative to the global executive would be to create a new regional governance organization that could address the security concerns present in Pashtunistan and throughout the Muslim world. The scope of this organization, an alliance of Muslim nations who aid one another in addressing internal and external security concerns, would be unprecedented in the Muslim world, but there is a model present for how to build this organization. NATO served its intended purpose throughout the Cold War and provided reassurance to states as they confronted post-Cold War difficulties and transnational terror. A similar organization, made of Muslim nations and designed to provide security and governance assistance to other Member Nations, could serve as a viable alternative to the global executive and staunch the flow of transnational terror from Pashtunistan.

\section{A. The Establishment of NATO, Its Stated Goals, and Current Troubles}

To properly understand how this proposed organization would work, it is necessary to have a cursory understanding of NATO and the current challenges the alliance faces. This understanding is integral to extrapolating how a NATO-like organization of Muslim nations would be constituted and operated.

Following World War II, at the outset of the Cold War, the signatories of NATO met in Washington D.C. to agree to a security framework. President Truman and the other signatories felt this agreement was crucial to countering the potential of the Soviets enlarging their sphere of influence, and therefore communism, throughout the world. ${ }^{100}$ The self-defense portion of the treaty allowed parties, pursuant to Article 51 of the United Nations Charter, to invoke the right of collective or individual self-defense if any of the member

100. See NATO EnLARgement 32 (Ted Galen Carpenter \& Barbara Conry eds., 1998). 
states were attacked. ${ }^{101}$ This provision of the treaty was not invoked until after the terrorist attacks of September 11, 2001.102

Following the collapse of the Soviet Union, NATO developed a new strategic concept that provided an increased focus on threats outside of Russia or its surrogates. ${ }^{103}$ This reformulation of the purpose of NATO explicitly recognized how NATO security interests could be impacted by "acts of terrorism, sabotage and organised crime, and by the disruption of the flow of vital resources."104 NATO further articulated their realization that "[e]thnic and religious rivalries, territorial disputes, inadequate or failed efforts at reform, the abuse of human rights, and the dissolution of states can lead to local and even regional instability." 105 While this modernization of NATO shows an adaptive and forward-thinking organization, the alliance is not without its issues.

Foremost among the current issues surrounding NATO is the perception that it is no longer relevant because Member States do not have identical levels of commitment to the organization and its aims. In 2008, Defense Secretary Gates expressed his concern about the level of commitment by NATO Member States when he said, "we must not-we cannot-become a two-tiered Alliance of those who are willing to fight and those who are not. Such a development, with all its implications for collective security, would effectively destroy the Alliance."106 This concern that some nations are unwilling to fight has the potential to erode the alliance from within. This sentiment and fear of erosion is

101. North Atlantic Treaty art. 5, Apr. 4, 1949, 63 Stat. 2241, 34 U.N.T.S. 243, which states in relevant part:

The Parties agree that an armed attack against one or more of them in Europe or North America shall be considered an attack against them all and consequently they agree that, if such an attack occurs, each of them, in exercise of the right of individual or collective self-defence recognized by Article 51 of the Charter of the United Nations, will assist the Party of Parties so attached by taking forthwith, individual and in concert with the other Parties, such action as it deems necessary, including the use of armed force, to restore and maintain the security of the North Atlantic area.

102. See, e.g., Ben Armbruster, Erdogan Suggests Invoking Article 5 of NATO Charter to Protect Turkey's Border with Syria, THINK PRogress (Apr. 12, 2012, 11:53 AM), http:/thinkprogress.org /security/2012/04/12/463235/erdogan-article-5-syria/?mobile=nc.

103. See The Alliance's Strategic Concept, NATO (Apr. 24, 1999), http://www.nato.int/ cps/en/natolive/official_texts_27433.htm.

104. Id.

105. Id.

106. Robert M. Gates, United States Secretary of Defense, Speech Delivered at the Munich Conference on Security Policy (Feb. 1, 2008), available at www.defenselink.mil /speeches/speech.aspx?speechid=1214. 
shared by some European members. ${ }^{107}$ This could be why the "[p]erception in degree to which NATO is deemed essential for security has dropped by an average of 13 percentage points from 2002 to 2007 [in European nations]... [and only] in the United States has the perception of the value of the alliance increased." 108

These current issues, while significant; are to be expected for an organization that is sixty-three years old and has been committing troops to combat operations for the past twelve years. A NATO-like organization comprised of Muslim nations would confront similar issues, but if it had the success and resiliency of NATO, it would be incredibly beneficial to Muslim nations throughout the Middle East and Southwest Asia.

\section{B. The Potential for and Issues Presented by a NATO-like Organization Comprised of Muslim Nations}

When addressing the potential of a Muslim NATO-like organization to intervene in Pashtunistan, it is essential to understand the legal context within which such an organization would operate. Of singular importance is the fact that nothing in the United Nations Charter "precludes the existence of regional arrangements or agencies for dealing with such matters relating to the maintenance of international peace and security as are appropriate for regional action provided that such arrangements or agencies and their activities are consistent with the Purposes and Principles of the United Nations." 109 Additionally, the United Nations Security Council retains the right "where appropriate, [to] utilize such regional arrangements or agencies for enforcement action under its authority." 110 These two provisions provide solid footing for this organization to establish itself and operate under the auspices and approval of the United Nations.

Another indicator that there is a strong potential for a Muslim NATO-like organization is the existence of the Arab League. The Arab League was formed in 1945 to 'look after their members' economic, political, cultural, national and religious interests . . . [and to help] the Arab world grow economically and culturally, while finding solutions to

107. Mihalka, supra note 24, at 62 (former Spanish Prime Minister, Jose Maria Aznar called NATO a "zombie organization due to the lack of interest from the U.S. side topped by the lack of commitment from the European allies").

108. Id. at 57 .

109. U.N. Charter art. 52, para. 1.

110. U.N. Charter art. 53, para. 1. 
resolve conflicts both within the league and outside of it."111 While this twenty-one-member organization could serve as a vessel for the creation of a NATO-like organization, ${ }^{112}$ it would need to overcome criticisms of ineffectiveness, disunity, poor governance, and over-representation of Arab dictatorships at the expense of the people. ${ }^{113}$

There is reason for optimism that the Arab League could expand its role throughout the region. Recently, during the uprising in Libya, the Arab League requested that the United Nations Security Council impose a no-fly zone over Libya. ${ }^{114}$ This action is indicative of two potential shifts in the organization's efficacy in dealing with its Member States' security issues. First, this could signal a shift away from the Arab League supporting autocratic leaders. While the Member States have repeatedly been criticized for protecting dictators and shielding each other from any sort of human rights criticism, the Arab Spring and its aftershocks may have eliminated this behavior.115 Additionally, calling for action could be a sign of Arab nations acknowledging the need to prevent the emergence of ungoverned areas within the region.

Another reason to be optimistic that the Arab League could become more relevant is the organization's call for international intervention in Syria. In June 2012, the head of the Arab League, Nabil Elaraby, requested that the crisis in Syria be submitted to the United Nations Security Council "as a threat to world peace and security." 116 While this is a positive sign, the next step would be a request from the Arab League to the United Nations for authority to intervene with a multinational force. It is encouraging that we may be closer to that coming to pass. In late September 2012, the emir of Qatar made a request to the United Nations for Arab nations to form a coalition to intervene in Syria

111. Presentation of the Arab League, League of ARAB STATES (Sep. 13, 2012), http://www. arableagueonline.org/hello-world/\#more-1.

112. Id. (outlining the Arab League member-states as: Algeria, Bahrain, Comoros, Djibouti, Egypt, Iraq, Jordan, Kuwait, Lebanon, Libya, Mauritania, Morocco, Oman, Palestine, Qatar, Saudi Arabia, Somalia, Sudan, Syria (currently suspended), Tunisia, United Arab Emirates, and Yemen).

113. Jonathan Masters, The Arab League, CounCIL ON FOREIGN RELATIONS (Jan. 26, 2012), http://www.cfr.org/middle-east/arab-league/p25967.

114. Ethan Bronner \& David E. Sanger, Arab League Endorses No-Flight Zone Over Libya, N.Y. TIMES (Mar. 12, 2011), http://www.nytimes.com/2011/03/13/world/middleeast/ 13libya.html?pagewanted=all\&_r=0.

115. See Kenneth Roth, Time To Abandon the Autocrats and Embrace Rights, HUMAN RIGHTS WATCH (2012), http://www.hrw.org/world-report-2012/time-abandon-autocrats-and -embrace-rights.

116. David Owen, We Can Intervene in Syria, With Russia's Blessing, The GUARDIAN (June 8, 2012, 2:16 PM), http:/www.guardian.co.uk/commentisfree/2012/jun/08/intervenesyria-russia-un-nato-kosovo-bosnia. 
due to the lack of international involvement in resolving the violence. ${ }^{117}$ This is an encouraging development and could provide a roadmap to resolve the existential security crisis in Pashtunistan.

While there is a tremendous amount of potential for the proposed organization, it is necessary, at a minimum, to acknowledge the issues presented by this organization. There are three obvious issues for this organization: the current sectarian tension between Sunni and Shi'a sects of Islam, the military capacity of potential Member States, ${ }^{118}$ and the ways Member States can address the Iran question. While a complete discussion of these issues is not central to this analysis, they must be addressed before a multinational military force is employed by this organization.

First, Shi'a-Sunni tension is critical because religious identification is the most prevalent identity marker in the Middle East, before ethnicity or national citizenship. ${ }^{119}$ Commentators have stated that this conflict "forges attitudes, defines prejudices, draws political boundary lines, and even decides whether and to what extent those other trends have relevance." 120 A balancing of power within the organization could weaken this conflict. While Shias only constitute 10 percent to 15 percent of the worldwide Muslim population, in the "Islamic heartland, from Lebanon to Pakistan . . . there are roughly as many Shias as there are Sunnis." 121 This sect population equality within the Middle East would require a Muslim NATO-like organization to self-govern and regulate itself to be an effective and legitimate organization. The birth of more representative governance in the Middle East, as evidenced by the Arab Spring and democratic protests throughout the region from 2011 to the present day, provides substantial hope that this is possible.

Next, the military capacity of the nations that would comprise this organization is questionable at the present time. While many nations in the region have militaries that could not adequately contribute to a

117. Colum Lynch \& Anne Gearan, At U.N., Qatar Emir Calls on Arab Nations to Intervene in Syria, WASH. PoST (Sep. 25, 2012), http://www.washingtonpost.com/world/na tional-security/at-un-qatar-emir-calls-on-arab-nations-to-intervene-in-syria/2012/09/25/4bf 05a9e-0758-11e2-a10c-fa5a255a9258_story.html.

118. This weakness would be a great place for global executive power to be used. Professionalizing and improving the militaries of these nations, like the United States has done for the Egyptian military, would aid this organization greatly.

119. See Shibley Telhami, 2006 Annual Arab Public Opinion Survey, BRookINGs INSTITUTE 3, available at www.brookings.edu/views/speeches/telhami20070208.pdf (discussing that $45 \%$ of respondents described being Muslim as the most important part of their identity, 29\% professing national citizenship was the most important, and $20 \%$ saying being Arab was the most important).

120. Vali NasR, The Shia Revival: How Conflicts Within Islam Will Shape the FUTURE 82 (2006).

121. Id. at 34 . 
Muslim NATO-like organization currently, 122 there are two nations that could carry the load in the near term. First, Turkey, currently a member of NATO, has a military that is one of the top ten militaries in the world with over half a million well-equipped and capable soldiers. ${ }^{123}$ Turkey's NATO membership has allowed its defensive capabilities to increase exponentially over the past twenty years. However, Turkey's commitment to NATO has lessened as Turkey turns its attention south and east and seeks to become a more significant player in the Muslim world. ${ }^{124}$ This drift may be useful as Turkey could be the founding member of this new organization, and it could depart NATO on positive, amicable terms. Turkey's military power, concomitant with its increased focus in the Muslim world, is an encouraging sign that the country would be willing to shoulder a noteworthy amount of the military requirements of a Muslim NATO, much like the United States does in the present-day NATO alliance. The Egyptian military also has the requisite capabilities to bear a disproportionate amount of the military burden of the organization, but its involvement is incredibly circumspect at this time due to their internal struggles after deposing President Morsi in July 2013.125

Finally, the most serious issue is Iran. The Iranian regime has shown, through its association with Hamas and Shiite insurgent groups in Iraq, that it is not currently interested in playing a regional role beyond advancing its own interests. ${ }^{126}$ Additionally, the nuclear issue and the threat of a regional conflict with Israel could negatively affect the formation of this proposed organization. The hope right now, if this problem is to be overcome, is that the sanctions on the Iranian

122. Based on on-going internal conditions the militaries of Iraq, Syria, Yemen, and Iran could not participate in any external operation and there would be no desire for Syrian or Iranian militaries to participate based upon the regimes currently controlling them.

123. See Yuri Mavashev, Turkey's Defense Power Grows at Pace to Be Envied, PRAVDA.RU (Jan. 31, 2012, 2:05 PM), http://english.pravda.ru/world/asia/31-01-2012/1203 76-turkey_defense_power-0/.

124. See generally Tarik Oğuzlu, Turkey's Eroding Commitment to NATO: From Identity to Interests, 35 WASH. Q. 153 (2012) (discussing how the post-9/11 world has caused Turkey to turn away from Europe, due to differences in interests, and back towards its Muslim neighbors.).

125. David D. Kirkpatrick, Army Ousts Egypt's President; Morsi Is Taken into Military Custody, N.Y. TIMES, July 3, 2013, http://www.nytimes.com/2013/07/04/world/middleeast/ egypt.html?pagewanted=all\&_r $=0$.

126. See generally Dexter Filkins, The Shadow Commander, The New Yorker, Sept. 30, 2013, http://www.newyorker.com/reporting/2013/09/30/130930fa_fact_filkins?currentP age $=$ all. 
government lead to an internal revolt that causes regime change internally along the vein of the Green Revolution seen in 2009.127

\section{Transnational Security Law Impacts of a NATO-like Muslim Organization in Pashtunistan}

The transnational security impacts of a Muslim NATO-like organization intervening in Pashtunistan cannot be overstated. First, it would allow for a relaxing of the drone program, which could lead to a decline in the recruitment of Pashtuns by radical Islamic movements. Additionally, it would foster a global security governance regime where regional as opposed to global solutions are sought, which is preferable. Finally, this organization could aid in the development of burgeoning representative governments in the Middle East as they encounter the difficulties inherent in embracing a new form of governance.

A global governance regime where regional as opposed to global solutions are valued would be an incredibly beneficial result of a Muslim coalition intervening in Pashtunistan. "The basic purpose behind any regional organization is to foster cooperation among the member states-to craft a common solution to a common problem ..., [which] can take the form of economic and/or financial integration, technical and cultural exchanges, or collective defense."128

The transnational terrorism problem emanating from Pashtunistan manifestly affects the Member States of the Islamic world. First, it directly threatens the existence of two governments- Afghanistan and Pakistan-and serves as a place to radicalize the youth of other nations in the region. Next, Pashtunistan's hosting of a transnational terrorist threat invites the actions of global executives that further destabilize the region. Finally, Pashtunistan's downward spiral, in terms of security and governance, is a millstone around the neck of a region that is attempting to remake itself through a more representative style of government and discourse following the so-called Arab Spring.

It is this paper's contention that a regional solution is better suited to address the Pashtunistan "problem" and would lead to a better resolution. As Mariana Valverde contends, "[w]hat makes one scale more or less suited to a particular governance task is not simply size, but also its qualitative dimension-in other words, the kind of priorities

127. See generally Robert Mackey, A Green Revolution for Iran?, N.Y. TIMES (June 10, 2009), http://thelede.blogs.nytimes.com/ 2009/06/10/a-green-revolution-for-iran/.

128. Davis Brown, The Role of Regional Organizations in Stopping Civil Wars, 41 A.F. L. REV. 235, 236-37 (1997). 
it implicitly sets as certain objects, rather than others."129 The regional, and not the global, scale is best suited to address the transnational security problem that is Pashtunitan, if it prioritizes the issue appropriately.

A drone program overseen by a global executive inarguably has both its supporters and detractors-positives and negatives. As discussed supra, numerous observers have commented that the drone program serves to radicalize the Pashtuns and acts as a rallying cry for the Islamic fundamentalist recruiter. ${ }^{130}$ The introduction of a Muslim military force in Pashtunistan could eliminate this fundamentalist recruiting tool. Removing this rallying cry of Islamic fundamentalists, without relieving any pressure on the safe haven they currently enjoy in Pashtunistan, could serve to reduce the attractiveness of fundamentalist movements. With Western presence in Iraq no longer a rallying cry, the fundamentalist movement could see a significant drop in its ranks if the drone program's role was lessened.

The intervention in Pashtunistan with a multi-national Muslim force would also signal that the global rule of law is now appropriately valued by modern governments in the Islamic world. This relaxing of the drone policy and Muslim intervention in Pashtunistan would provide time for a comprehensive global agreement to be developed to address the legal issues surrounding drone programs and their expansion throughout the communities of nations. All of these developments would be positive and beneficial to the West and the Middle East, but only if the intervention in Pashtunistan addressed the security concerns emanating from there and Western nations were convinced that their transnational terror concerns were contained and eliminated.

One apt example of a regional organization placing a priority on addressing an ungoverned space and successfully intervening, as endorsed by Valverde, is seen in the African Union's action targeting the Al-Shabaab terror network in Somalia. In 2007, Al-Shabaab, an Al Qaeda affiliate founded in Somalia, was on the verge of turning Somalia into a transnational terrorism headquarters on the scale of Afghanistan

129. Mariana Valverde, Jurisdiction and Scale: Legal "Technicalities" as Resources for Theory, 18 SoC. \& LEGAL STUD. 139, 147 (2009).

130. See Ashley Boyle, U.S. Drones Policy: Strategic Frameworks and Measuring Effects, AMERICAN SECURITY PROJECT (Aug. 20, 2012, 3:59 PM), http://americansecurityproject.org /blog/2012/event-review-u-s-drones-policy-strategic-frameworks-and-measuring-effects/ (discussing how Al Qaeda in the Arabian Peninsula uses the drone program extensively in its recruiting efforts). 
prior to September 11, 2001.131 In late 2011, Al-Shabaab, largely unchecked, controlled more than half of Somalia and was involved in training transnational terrorists, launching pirate attacks, and collecting millions from exports. ${ }^{132}$ In September 2012, a joint Kenyan and African Union military force expelled Al-Shabaab from its last stronghold, the city of Kismayo. ${ }^{133}$ Somalia analyst Tres Thomas opined that the catalyst for defeating Al-Shabaab was the "actual coordination between Kenya, Ethiopia, the Somali government, AMISOM, and the proxy militias that all of these groups used to combat al Shabaab ... [and it's] only recently that they had a coherent and collective vision in terms of how to defeat al Shabaab on the battlefield."134 This portends well for the potential effects of a Muslim NATO-like organization intervening in Pashtunistan. Al-Shabaab, like the Taliban and other Al Qaeda-affiliated organizations, is a homegrown movement that was successfully confronted by a diverse alliance of neighboring African nations. ${ }^{135}$

A final rationale for supporting a NATO-like organization intervening in Pashtunistan, as opposed to a global executive, is the tension-reducing effects it could have across the Muslim world. Many Muslim nations view the Western classification of controversies and conflicts in terms of freedom as disingenuous. Muslim nations often feel that the talk of freedom is instead a "willful insult by a powerful West intent on maintaining its dominance in Muslim lands ... [and] if these differences continue to be viewed through these conflicting prisms, there is little hope for an accommodation to ameliorate, let alone stop" violence and aggravation between the West and the Muslim world. ${ }^{136}$ While this is a formidable reason to allow the Muslim community to address Pashtunistan, it cannot be done if it simply serves as a modern form of appeasement.

131. See generally David Shinn, Al Shabaab's Foreign Threat to Somalia, ForeIGN POLICY RESEARCH INSTITUTE (2011), http://www.fpri.org/docs/alshabaab.pdf (discussing how Al-Shabaab's control of significant regions of Somalia resembles the Taliban).

132. See Jeremy Jacobson, Daniel Nisman \& Jay Radzinski, Winning the War Against Al Qaeda in Africa, WALL ST. J. (Oct. 31, 2012), http://online.wsj.com/article/SB100014240 $52970204840504578086664192947422 . \mathrm{html}$.

133. See id.

134. Armin Rosen, How Africa's Most Threatening Terrorist Group Lost Control of Somalia, ATLANTIC (Sep. 21, 2012, 10:00 AM), http://www.theatlantic.com/international/ar chive/2012/09/how-africas-most-threatening-terrorist-group-lost-control-ofsomalia/262655/\#.

135. See id.

136. Abdulaziz H. Al-Fahad, Globalization and Its Discontents, ForeIGN POLICY (Sep. 18, 2012, 2:53 PM), http://mideast.foreignpolicy.com/posts/2012/09/18/globalization_and_ its_discontents (discussing how the anti-Islam film produced in California and placed on YouTube impacts discussions and viewpoints of the Islamic world). 


\section{CONCLUSION}

In addressing the Pashtunistan problem, the status quo is not maintainable or suited to resolve the issues present in this region. It is naïve to believe that a more active Arab League, or Muslim NATO-like organization, would come without issues. Consensus building among the Member States on how to deploy and exercise the use of force would be contentious, just like it is among the signatories of the North Atlantic Treaty. ${ }^{137}$ Moreover, an activist group of Muslim nations would likely cause great concern among the Israeli elite and could be a catalyst for increased tension between the Arab Member States and Iran. ${ }^{138}$ While risk is present in this proposal, a greater expansion of global executive power is more troubling and not likely to slacken or eliminate the transnational terror originating from Pashtunistan. The global executive would find his power more effectively utilized by encouraging and facilitating a regional solution that is acceptable to a global audience.

137. See Mihalka, supra note 24, at 63 ("NATO is a consensus-based organization but there is no consensus about how to proceed with the global war on terrorism, or even if there is such a war. This lack of agreement severely hampers the development of a common strategy in Afghanistan.").

138. Iran is a Muslim country, but is largely made up of Persian people with an Arab minority of three million citizens, or approximately $5 \%$ of the population. See Lionel Beehner, Iran's Ethnic Groups, CounCIL ON FOREIGN RELATIONS (Nov. 29, 2006), http://www.cfr.org/iran/irans-ethnic-groups/p12118. 
